\title{
Meconopsis merakensis var. merakensis (Papaveraceae), a new record for India
}

\author{
Kanwal K.S. ${ }^{*}$, Tiwari U.L. ${ }^{2}$, Lodhi M.S. ${ }^{3}$ \& R.S. Rawal ${ }^{4}$ \\ ${ }^{1}$ G.B. Pant National Institute of Himalayan Environment (NIHE), Himachal Regional Centre, Mohal Kullu, Himachal Pradesh - 175 126, India. \\ ${ }^{2}$ Botanical Survey of India, Arunachal Pradesh Regional Centre, Itanagar, Arunachal Pradesh - 791 111, India. \\ ${ }^{3}$ G.B. Pant National Institute of Himalayan Environment (NIHE), North East Regional Centre, Itanagar, Arunachal Pradesh - 791 113, India. \\ ${ }^{4}$ G.B. Pant National Institute of Himalayan Environment (NIHE), Kosi-Katarmal, Almora, Uttarakhand - 263 643, India. \\ *E-mail: kskanwal03@gmail.com
}

\begin{abstract}
Meconopsis merakensis Tosh.Yoshida, R.Yangzom \& D.G.Long var. merakensis is reported for the first time in India, from the Tawang district of Arunachal Pradesh. It has deeply nodding, bowl-shaped, bluish or purplish flowers and the tip of the elongate rachis is often curved. Morphological characteristics of the species were examined and photographic plates are provided in the present communication for easy recognition of this taxon in the field.
\end{abstract}

Keywords: Arunachal Pradesh, Himalaya.

\section{Introduction}

Meconopsis Vig. is one of the most distinctive and beautiful genera of the family Papaveraceae (Taylor \& Cox, 1934; Grey-Wilson, 2014). The genus was first described by Viguier in 1814 who named it poppy-like (from Greek mekon = poppy, opsis = likeness). Mostly herbaceous, the genus is native to the high-altitude areas of the Himalayas distributed from Pakistan, India, Nepal, Bhutan, Myanmar, to China. Meconopsis comprises c. 50-80 species (GreyWilson, 2014; Xiao \& Simpson, 2017) with 16 species in India (Debnath \& Nayar, 1993). The genus is characterized by large saucer-shaped blue, yellow, white, purple and red flowers. The majority of Meconopsis species are used in traditional herbal medicine systems (Kala, 2003) and some species are also cultivated as ornamentals for their attractive

Received: 03.04.2020; Revised \& Accepted: 27.07.2020

Published Online: 30.09.2020 flowers. The genus exhibits wide morphological variation in terms of height, ranging from a few centimetres to 2 meters. The plants occur along a wide altitudinal gradient from 3000 to $5800 \mathrm{~m}$. Meconopsis has been defined by several authors based on morphological (Prain, 1906; Kingdon-Ward, 1926; Taylor \& Cox, 1934; Wu \& Chuang, 1980; Grey-Wilson, 2014), cytological (Kumar et al., 2013) and molecular phylogenetic traits (Xiao \& Simpson, 2015, 2017). Morphological and recent molecular studies have raised concern regarding the taxonomy of Meconopsis and Papaver L. Comprehensive molecular studies need to be carried out to resolve the taxonomical ambiguity of the genera. In the present study, the most recent and authentic literature is followed for taxonomical treatment of Meconopsis merakensis var. merakensis.

The high altitude areas of eastern Himalaya remain largely botanically unexplored and the regions hold great potential for the discovery of many new species. During the floristic study of the highaltitude wetland flora of the Tawang district of Arunachal Pradesh, specimens of Meconopsis were collected from different locations in the study area during the summer and rainy seasons of the years 2016 to 2018. One interesting Meconopsis taxon was collected from the alpine rocky slope near Nagula Tso wetland area (Latitude N 27 39'04.07" and Longitude E 91 ${ }^{\circ} 51^{\prime} 48.95^{\prime \prime}$ at an altitude of around $4200 \mathrm{~m}$ ) in the rainy season in 2018. The Nagula Tso Wetland Complex (NWC) is situated North of the Tawang township of western Arunachal 
Pradesh, bordering China (Tibet). The NWC contains more than 100 permanent alpine freshwater lakes distributed between 3000 to 4420 $\mathrm{m}$ altitudes. Nagula Tso lake is located between Latitude N 27 $39^{\prime} 16.27^{\prime \prime}$ and Longitude E $91^{\circ} 51^{\prime} 48.09^{\prime \prime}$ at around $4120 \mathrm{~m}$ altitudes, and is locally known as Gribtsang Tsho (Fig. 1). The entire Nagula Tso area is a pilgrimage site of the Buddhist community (Monpa) of Tawang.

The collected specimen possessed a blue flower, spiny hairs covering the stem and leaves, and a narrow, curved tip of the elongate rachis. A perusal of the literature revealed that this specimen belongs to Meconopsis merakensis Tosh.Yoshida, Yangzom \& D.G.Long var. merakensis, which has recently been described from Merak and Sakten localities of Tashigang district in Bhutan (Yoshida et al., 2017). Therefore, the present communication reports it as a new distributional record for the flora of India. A detailed description and photographs of the taxon are provided for its identification.

\section{Materials and Methods}

The standard taxonomic procedure was adopted to process the collected specimens (Rao \& Sharma, 1990). The voucher specimens were deposited at the herbariums of the G.B. Pant National Institute of Himalayan Environment (GBPI) and Botanical Survey of India Arunachal Pradesh Regional Centre (ARUN) for future reference. After a critical study of herbarium specimens housed at various institutions such as the Botanical Survey of India, Itanagar (ARUN), State Forest Research Institute (SFRI), Itanagar, Rajiv Gandhi University (RGU) and International online herbaria of Royal Botanic Gardens, Kew, United Kingdom and review of relevant literature (Wu \& Chuang, 1980; GreyWilson, 2014; Yoshida et al., 2016; Xiao \& Simpson, 2017) and further personal communication with the experts (Dr. Grey-Wilson \& Mr. T. Yoshida), the specimen was identified as Meconopsis merakensis var. merakensis. The distribution maps were prepared using the software QGIS 3.12.1-Bucuresti (QGIS Development Team, 2020)

\section{Taxonomic treatment}

Meconopsis merakensis Tosh.Yoshida, Yangzom \& D.G. Long var. merakensis, Sibbaldia 14: 89. 2017[“2016”]. Type: BHUTAN, Trashigang district, Merak region, 03.07.2014, $4290 \mathrm{~m}, R$. Yangzom \& C. Wangmo 730 (THIM!). Figs. 1 \& 2

Herbaceous, monocarpic, 30-60 cm tall, whole plant covered with brown or white patent spiny hairs throughout; stems $12-30 \mathrm{~cm}$ long, spreading, with 2-5 mm long bristles. Basal leaves many; petioles broadly linear, membranous, $2-8 \mathrm{~cm}$ long; lamina mostly strap-shaped or linear-oblong, margins entire or wavy, occasionally coarsely toothed, acute or rounded at apex, densely covered with patent spiny hairs on both surfaces. Inflorescence racemose, tip of elongate rachis often gradually narrowed and curved. Flowers 4-12, on 2-4 cm long pedicels, usually nodding, bowlshaped, 2-6 cm across. Sepals 2 or 3, oblong, 1-1.6 $\mathrm{cm}$ long. Petals 4-6, broadly obovate-suborbicular, 2-4 cm long, margins entire, bluish or purplish. Stamens numerous; filaments filiform, 6-8 $\mathrm{mm}$ long, yellow. Ovary ovoid, densely bristly; style 1$4 \mathrm{~mm}$ long; stigma 4-7-lobed, greenish yellow. Capsules sub-cylindrical, bristly, 3-3.5 cm long, with prominently thick conical base.

Flowering \& fruiting: Flowering from July to August and fruiting from August to September.

Habitat: The plants occur on Northwest facing alpine meadows and rocky slopes in high altitude Himalaya, between $3800-4500 \mathrm{~m}$. The species is very rare and occurs in the field with scattered populations confined to some isolated pockets in the Northwest regions of the Nagula lake area. The Monpa community of Tawang has strictly prohibited the collection of fuel wood, fodder and other forest resources from the Nagula Tso sacred landscape under their community customary laws.

Distribution: Eastern Bhutan and now in India.

Specimen examined: INDIA, Arunachal Pradesh, District Tawang, Nagula Tso N $27^{\circ} 39^{\prime} 04.07^{\prime \prime} \mathrm{E}$ 91 51'48.95", 4200 m, 30.07.2018, K.S. Kanwal \& M. Ori SERB/KSK/1203 (ARUN, GBPI). 

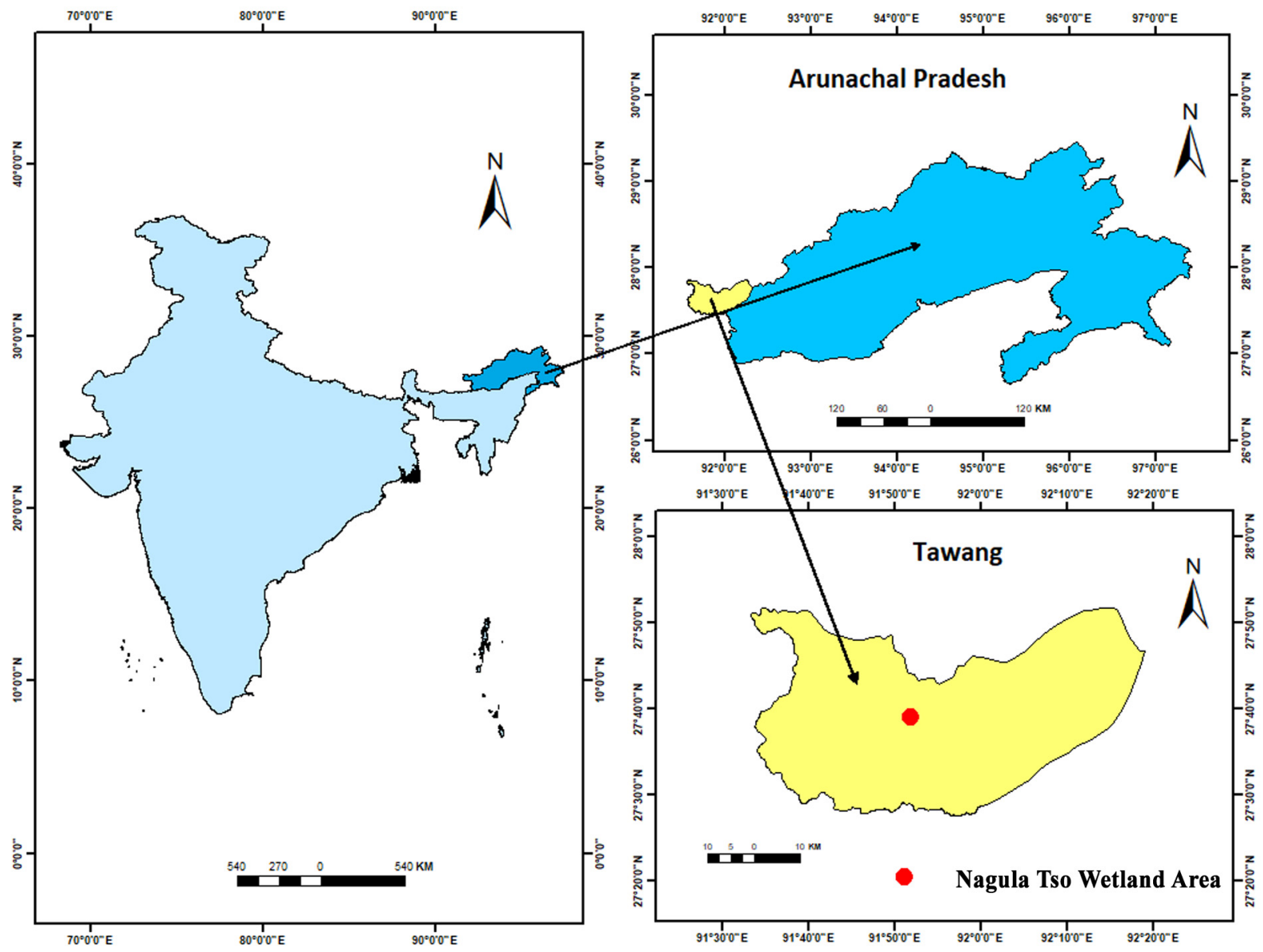

Fig. 1. Map area and the collection point of Meconopsis merakensis Tosh.Yoshida, Yangzom \& D.G.Long var. merakensis in the Tawang district[drawn using the software QGIS 3.12.1 -Bucuresti (QGIS Development Team, 2020)].

Conservation notes: Meconopsis merakensis var. merakensis faces threats from livestock, mainly from trampling by yaks and horses, unregulated tourism, development works that result in the destruction and fragmentation of the species' habitat. In the future, the species may face further threats due to climate change. Seven species of Meconopsis have shown an upward shift in mean elevation of $302.3 \mathrm{~m}$ between the pre 1970s (1922-1969) and the post 1970s (1970-2016) in the Himalaya-Hengduan Mountains region (He et al., 2019). Endemic and rare plant taxa, such as $M$. merakensis var. merakensis, with very small populations and special habitats, require specific conservation measures such as the development of an on-site Meconopsis garden for the germplasm conservation in the Tawang district.
Notes: The detailed analysis carried out here revealed that $M$. merakensis var. merakensis is close to $M$. prainiana Kingdon-Ward var. prainiana in having four-petalled flowers, hairy stems and in leaf structure but differs by its longer and sub-cylindrical capsules and stems less densely covered with spiny hairs (Yoshida et al., 2017[“2016"]). Meconopsis merakensis has two varieties, var. merakensis characterised by its bluish or purplish flowers, and M. merakensis var. albolutea Tosh.Yoshida, Yangzom \& D.G.Long distinguished by its white or yellow flowers (Yoshida et al., 2017). The latter variety is distributed in Bhutan and western Arunachal Pradesh, India.

Key to Meconopsis prainiana and M. merakensis and their varieties (adopted from Yoshida et al., 2017)

1. Capsules ellipsoid, $1.5-2.5 \mathrm{~cm}$ long; stems quite densely covered with patent spiny hairs .... . 2 

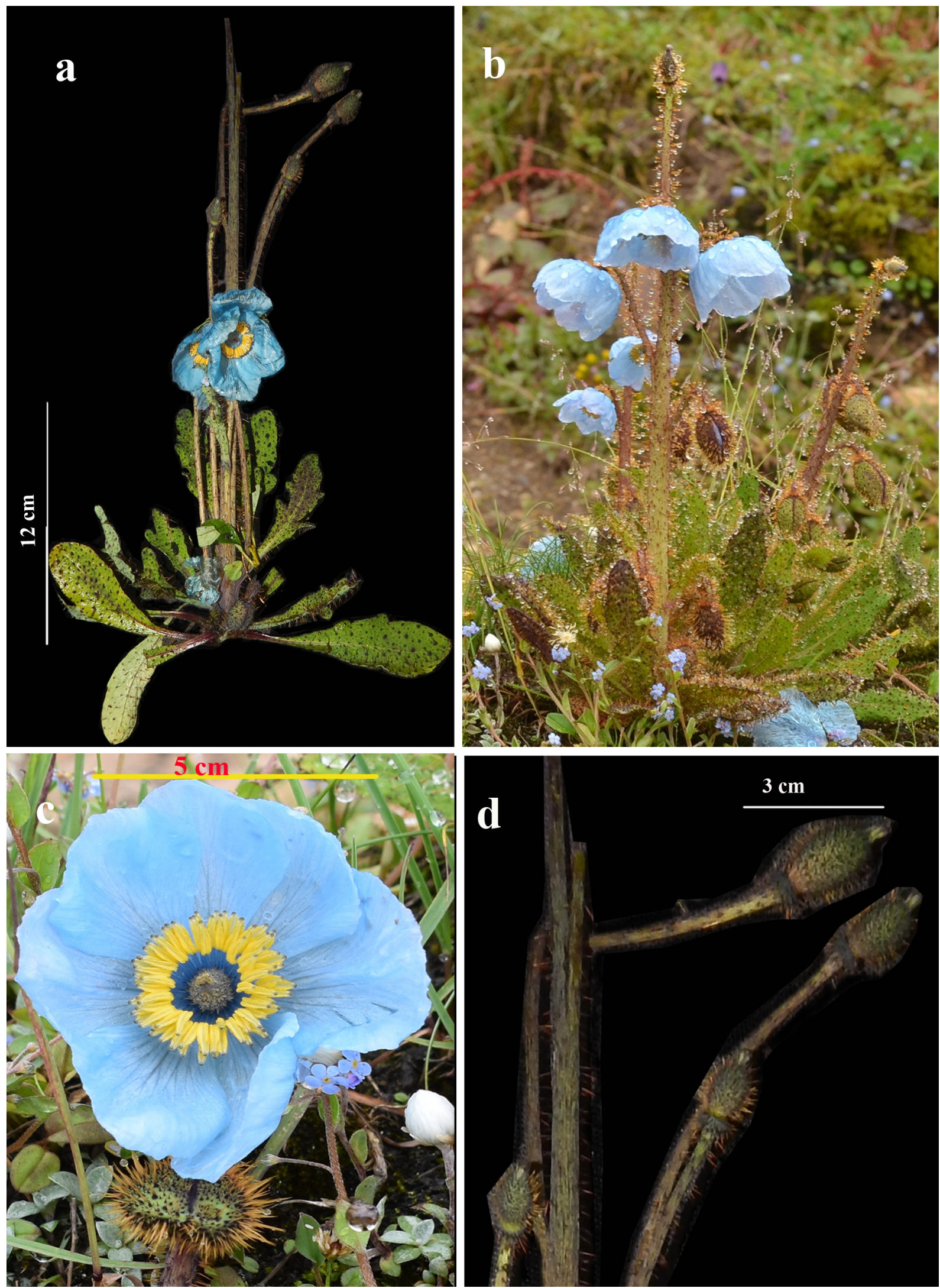

Fig. 2. Meconopsis merakensis Tosh.Yoshida, Yangzom \& D.G.Long var. merakensis: a. Habit; b. A plant in natural habitat; c. Flower - enlarged view; d. Capsules (from K.S. Kanwal \& M. Ori SERB/KSK/120g; photos by Dr. K.S. Kanwal). 
1. Capsules sub-cylindrical, $3.0-3.7 \mathrm{~cm}$ long; stems less densely covered with spiny hairs ...

2. Petals pale blue to purple

M. prainiana var. prainiana

2. Petals pale yellow ....... M. prainiana var. lutea

3. Petals bluish or purplish

M. merakensis var. merakensis

3. Petals white or yellow

M. merakensis var. albolutea

\section{Acknowledgements}

The authors are highly thankful for financial support from the Research project (F.No. EMR/ 2014/000408) funded by the Science \& Engineering Research Board (SERB), Department of Science and Technology (DST), Government of India. The second author is thankful to the Director, Botanical Survey of India and Head of Office, BSI APRC, Itanagar, Arunachal Pradesh for necessary facilities and encouragement. The authors are also thankful to the local community for valuable information about the Nagula Tso wetland area. The authors gratefully acknowledge the help of Mr. Toshio Yoshida, Chiba, Japan and Dr. Magnus L. Liden, Uppsala University, Sweden for species identification and valuable suggestions. We are also highly grateful to the Department of Environment and Forest, Govt. of Arunachal Pradesh and the Indian Army for giving necessary permission and support during the field study.

\section{Literature Cited}

DEBNATH H.S. \& M.P. NAYAR 1993. Papaveraceae. In: SHARMA B.D. \& N.P. BALAKRISHNAN (eds.), Flora of India. Volume 2. Botanical Survey of India, Kolkata, pp. 10-27.

GREY-WILSON C. 2014. The genus Meconopsis: blue poppies and their relatives. Royal Botanic Gardens, Kew.

HE X., BURGESS K.S., YANG X.F., AHRENDS A., GAO
L.M. \& D.Z. LI 2019. Upward elevation and northwest range shifts for alpine Meconopsis species in the Himalaya-Hengduan Mountains region. Ecology and Evolution 9(7): 4055-4064. https://doi.org/10.1002/ ece 3.5034

KALA C.P. 2003. Medicinal plants of Indian trans Himalaya: focus on Tibetan use of medicinal resources. Bishen Singh Mahendra Pal Singh, Dehradun.

KINGDON-WARD F. 1926. Notes on the genus Meconopsis, with some additional species from Tibet. Annals of Botany 40: 535-546. https://doi.org/10.1093/ oxfordjournals.aob.a090036

KUMAR S., JEELANI S.M., RANI S., GUPTA R.C. \& S. KUMARI 2013. Cytology of five species of subfamily Papaveroideae from the Western Himalayas. Protoplasma 250: 307-316. https://doi.org/10.1007/s00709-0120413-7

PRAIN D. 1906. A review of the genera Meconopsis and Cathcartia. Annals of Botany 20(4): 323-370. https:// doi.org/10.1093/oxfordjournals.aob.a089107

QGIS DEVELOPMENT TEAM 2020. QGIS Geographic Information System. QGIS V.3.12.1-Bucuresti. Open Source Geospatial Foundation Project. Available at: https://qgis.osgeo.org

RAO R.R. \& B.D. SHARMA 1990. A manual for herbarium collections. Botanical Survey of India, Kolkata.

TAYLOR G. \& E.H.M. COX 1934. An account of the genus Meconopsis. New Flora \& Silva Ltd., London.

VIGUIER A.L.G. 1814. Histoire Naturelle, Médicale et Économique des Pavots et des Argemones. Jean Martel Ainé, Montpellier.

WU Z.Y. \& H. CHUANG 1980. A study on the taxonomic system of the genus Meconopsis. Acta Botanica Yunnanica 2: 371-381.

XIAO W. \& B.B. SIMPSON 2017. A new infrageneric classification of Meconopsis (Papaveraceae) based on a well-supported molecular phylogeny. Systematic Botany 42(2): 226-233. https://doi.org/10.1600/ 036364417 X695466

XIAO W. \& B. SIMPSON 2015. Phylogenetic analysis of Meconopsis (Papaveraceae) and evaluation of two controversial taxonomic species. Lundelia 18: 14-18. https://doi.org/10.25224/1097-993X-18.1.14

YOSHIDA T., YANGZOM R., \& D.G. LONG 2017[“2016"]. Dancing butterflies of the East Himalayas - new Meconopsis species from East Bhutan, Arunachal Pradesh and South Tibet. Sibbaldia 14: 69-96. 